\title{
Influence of ladle shroud and change in its position on liquid steel flow hydrodynamic structure in six-strand tundish
}

\author{
Wpływ wylewu osłonowego kadzi stalowniczej \\ i zmiany jego położenia \\ na strukturę hydrodynamiczną przepływu ciekłej stali \\ w sześciowylewowej kadzi pośredniej
}

\begin{abstract}
This paper presents the numerical simulation results of the liquid steel flow in a six-strand tundish used for casting billets. The influence of using a ladle shroud, changing its immersion depth in liquid steel on the transition zone, and shaping the liquid steel volume flow were tested. Three positions of the ladle shroud immersion depth in liquid steel were checked. The computer calculation results have shown that the use and position change of the ladle shroud locally influences the shape of the liquid steel hydrodynamic structure in the tundish. The numerical simulations were carried out using the Ansys-Fluent computer program.
\end{abstract}

Keywords: tundish, continuous casting of steel, numerical simulation, ladle shroud

\section{Streszczenie}

W niniejszej pracy przedstawiono wyniki symulacji numerycznych przepływu ciekłej stali w sześciowylewowej kadzi pośredniej przeznaczonej do odlewania wlewków kwadratowych. Testowano wpływ zastosowania wylewu osłonowego i zmiany jego głębokości zanurzenia w ciekłej stali na zakres strefy przejściowej i kształtowanie udziałów przepływu ciekłej stali. Sprawdzono trzy głębokości zanurzenia wylewu osłonowego w ciekłej stali. Rezultaty obliczeń komputerowych wykazały, iż zastosowanie i zmiana położenia wylewu osłonowego wpływa lokalnie na kształt struktury hydrodynamicznej przepływu ciekłej stali w kadzi pośredniej. Symulacje numeryczne zrealizowano z wykorzystaniem programu komputerowego Ansys-Fluent.

Słowa kluczowe: kadź pośrednia, ciągłe odlewanie stali, symulacja numeryczna, wylew osłonowy kadzi stalowniczej

Michał Bartosiewicz, Adam Cwudziński: Czestochowa University of Technology, Faculty of Engineering Production and Materials Technology, Department of Metals Extraction and Recirculation, Czestochowa, Poland; bartosiewicz.michal@wip.pcz.pl,cwudzinski.adam@wip.pcz.pl 


\section{Introduction}

The requirements on the metallurgical market force on production plants for the production of steel products with different properties. Therefore, new steel grades are sought in terms of chemical composition that are aimed at meeting customer requirements. This practice causes a significant expansion of sale offers that operate on the free market, which forces steel plants to implement the sequential casting process. The neuralgic stage during this process is the moment of mixing in the tundish two different steel grades in terms of chemical composition, which is defined by the range of the transition zone. Solutions aimed at reducing the time of the transition zone are constantly being searched, which minimizes the number of cast ingots (slabs, billets, or blooms) that do not meet grade standards [1-3]. The tundish is included in the group of flow reactors in which the hydrodynamic structure analysis consists on determining the volume of the plug, ideal mixing, and stagnant flow, which are described in detail in work [4]. The improvement of the liquid steel flow hydrodynamic structure in the tundish is obtained through results of the active flow volume increase (plug and ideal mixing). A known way to improve the liquid steel flow hydrodynamic structure is the modification of metal flow streams in the tundish working space using flow control devices FCD [5-9]. According to articles $[1,10,11]$, an FCD can identify the ladle shroud that influences the liquid steel flow in the tundish through modifying the main supplying stream. The use of the new FCD under industrial conditions is preceded through simulation research of the continuous steel casting process. Numerical simulations that reflect the actual liquid steel flow in a tundish have been widely used $[1,12,13]$. The computer calculation results after applying a previously verified mathematical model allow us to get to know the full view of the metal movement hydrodynamic structure in the working volume of the tundish and ladle shroud.

This paper presents the numerical simulation results of liquid steel flow in a six-strand tundish used in the continuous casting process of billets. The influence of the ladle shroud and change in its immersion depth in liquid steel on the hydrodynamic structure in the tundish were checked.

\section{Description of research object}

Computer calculations were performed on a virtual model of a six-strand delta type tundish characterized by a nominal capacity of $20 \mathrm{Mg}$. Figure 1 shows a model of the discussed object with the ladle shroud immersed to a depth of $0.2 \mathrm{~m}$ in liquid steel. The tundish is symmetrical with respect to the crossed surface through the ladle shroud axis perpendicular to the longest wall of the object. The liquid steel flow to a casting mold was carried out using single-piece well nozzles (SPWNs). The metal flow in the tundish was simulated without use of a ladle shroud (Case 1) and with use of a ladle shroud. Three immersion depths of the ladle shroud in liquid steel were tested: $0.1 \mathrm{~m}$ (Case 2), 
$0.2 \mathrm{~m}$ (Case 3), and $0.3 \mathrm{~m}$ (Case 4). The diameter of the main supplying stream and inner diameter of the ladle shroud was $0.05 \mathrm{~m}$. The SPWNs were located at intervals of $1 \mathrm{~m}$.

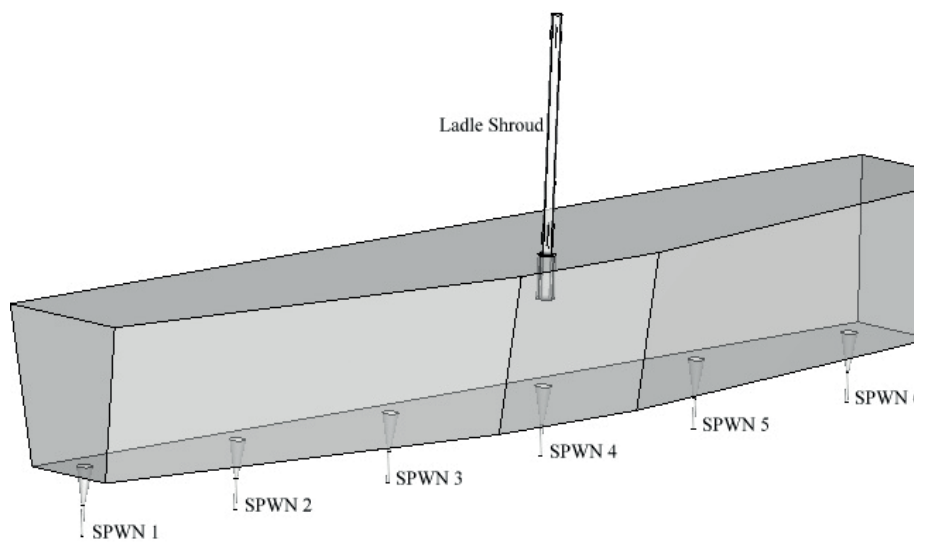

Fig. 1. Virtual model of discussed tundish with ladle shroud immersed at depth of $0.2 \mathrm{~m}$ in liquid steel

\section{Research methodology}

Virtual models of the considered tundish with variants of the ladle shroud immersion depth in liquid steel were performed in the Gambit computer program. The models of the studied objects were divided using a computational net, which contained between 421,000 and 434,000 control volumes (the difference in the number of control volumes depends on the geometry of the tested variants). The virtual objects were exported to the Ansys-Fluent computer program in which numerical simulations of liquid steel flow through the tested variants were carried out. In the calculations, the mathematical model solving the equations of mass, momentum, and energy was used, taking into account the turbulent nature of liquid steel flow described by the realizable $k-\varepsilon$ turbulence model. The continuous casting process of billets with dimensions of $0.13 \times 0.13 \mathrm{~m}$ with a casting velocity of $0.53 \mathrm{~m} \cdot \mathrm{s}^{-1}$ was simulated. The boundary condition through which the liquid steel flowed to the considered object was established at the beginning of the ladle shroud, which made it possible to simulate the metal movement in the entire volume of the ladle shroud. In the research case without the ladle shroud, the boundary condition of the inflowing liquid steel was determined in the same place as in the other cases. In all of the performed computer calculations, the identical input information of the inflowing liquid steel to the object was assigned. The liquid steel velocity on the inlet was set to $2.738 \mathrm{~m} \cdot \mathrm{s}^{-1}$, whereas the temperature was $1838 \mathrm{~K}$. The turbulent kinetic energy and dissipation rate of the kinetic energy on the inlet were calculated at $0.07496 \mathrm{~m}^{2} \cdot \mathrm{s}^{-2}$ and $0.82103 \mathrm{~m}^{2} \cdot \mathrm{s}^{-3}$, respectively. The physicochemical properties of liquid steel are described in work [1]. In each of the tested cases, the plane simulating the steel/tundish powder boundary was characterized by a zero 
tangential stresses wall. In this work, the losses of heat streams on the walls of the object were taken into account, which are described in detail in work [14].

The analysis of the transition zone was made in the considered tundish research variants. In the boundary condition corresponding to the place of the inflowed steel into the object, a tracer (continuous signal) was used, and the change in its concentration in the individual SPWNs was registered. The transition zone was established within a range of $20 \%$ to $80 \%$ of the concentration of the tracer. Furthermore, an analysis of the liquid steel flow types in the individual cases of the tundish was performed. This required the introduction of a pulse tracer at the boundary condition of the inflowed liquid steel into the object. Then, the residence time of the tracer in the tundish was determined through recording the change of its concentration in each SPWN. The method of calculating the plug, stagnant, and ideal mixing flow is broadly described in work [4]. In order to fully describe the hydrodynamic structure of the liquid steel flow in the considered tundish, flow fields were made on the crossed plane of the SPWN axes parallel to the longest wall of the object.

\section{Research results}

Figure 2 presents the liquid steel flow fields in the considered research variants. In all cases, the horizontal flow streams along the tundish bottom were observed (near SPWNs 3 and 4). In Cases 3 and 4, two horizontal circulation streams along the surface steel/tundish powder between SPWNs 3 and 4 were noticed. Furthermore, in Variants 1,2 , and 4, a horizontal circulation stream over SPWN 2 was observed. Additionally, in Case 2, two circulation streams along the upper surface of the object were noted (above SPWNs 3 and 5), whereas in Case 4, a circulation stream was observed between SPWNs 4 and 5. Analyzing the flow fields of all of the tested variants, the occurrence of liquid steel flow asymmetry was noticed. Case 3 saw the smallest asymmetry of the liquid steel flow among the tested variants.

The performed calculations made it possible to analyze the percentage flow volume of the active flow (plug and ideal mixing) and stagnant flow of the liquid steel in the examined tundish. Figure 3 shows the percentage volumes of the liquid steel plug flow for the individual research variants. Comparing the plug flow volumes in SPWNs 1 and 6 , slight differences between the variants of the tundish were noticed. The greatest discrepancies (between SPWNs 1 and 6) in the plug flow was recorded in Case $3(0.5 \%)$. The plug flow for SPWNs 3 and 4 was similar in all of the tested variants (only in the case of without the ladle shroud was the plug flow registered at $0.3 \%$ ). Whereas, between SPWNs 2 and 5, the greatest differences of the plug flow were observed. Only in Case 1, the identical values of the plug flow were noticed. The largest difference in the plug flow (between SPWNs 2 and 5) in Case 2 was noted (2.6\%). The average of the plug flow was calculated for all of the research variants. Thus, for Cases 1-4, the average of the plug flow was successively: $4.0,4.1,4.1$, and $4.3 \%$. 
a)

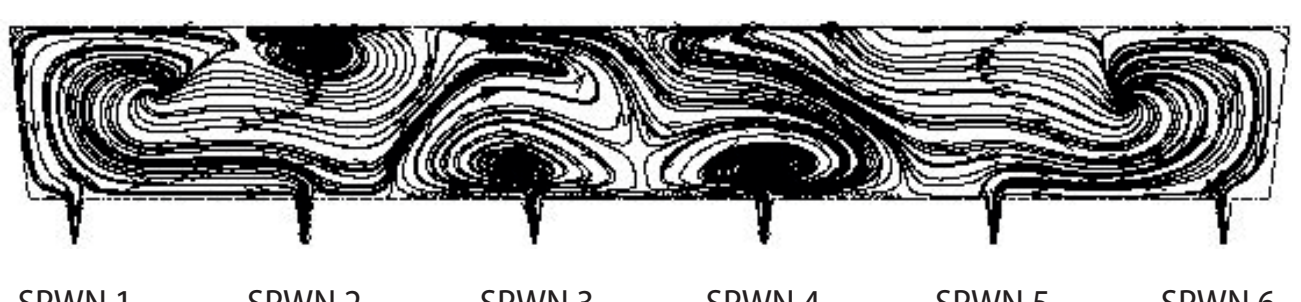

$\begin{array}{llllll}\text { SPWN } 1 & \text { SPWN } 2 & \text { SPWN 3 } & \text { SPWN 4 } & \text { SPWN 5 } & \text { SPWN 6 }\end{array}$

b)

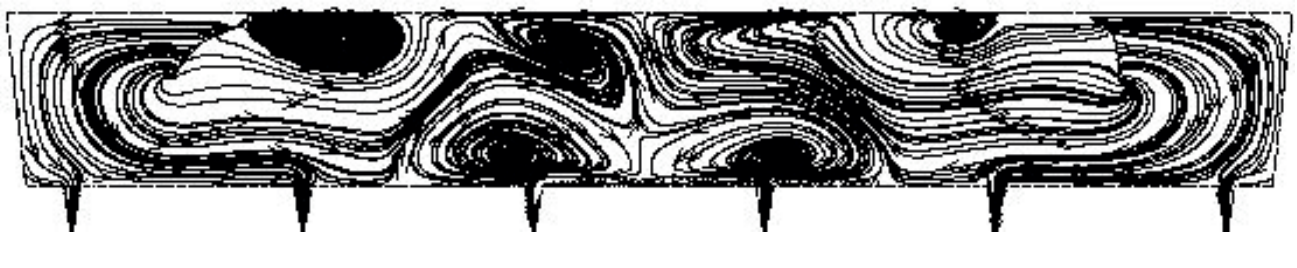

$\begin{array}{llllll}\text { SPWN } 1 & \text { SPWN } 2 & \text { SPWN } 3 & \text { SPWN } 4 & \text { SPWN } 5 & \text { SPWN } 6\end{array}$

c)

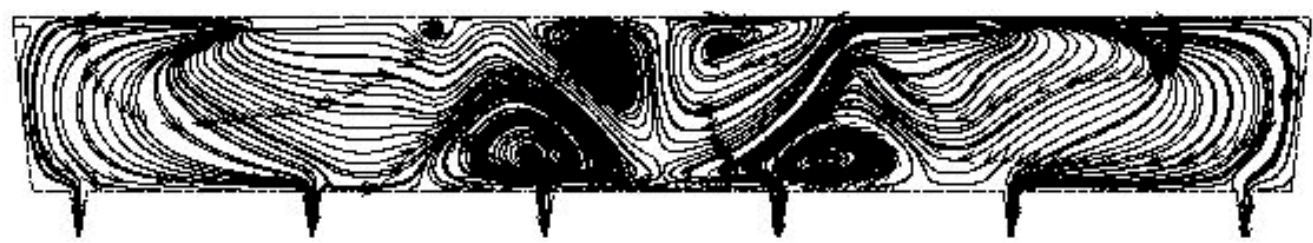

$\begin{array}{llllll}\text { SPWN } 1 & \text { SPWN } 2 & \text { SPWN 3 } & \text { SPWN } 4 & \text { SPWN } 5 & \text { SPWN 6 }\end{array}$

d)

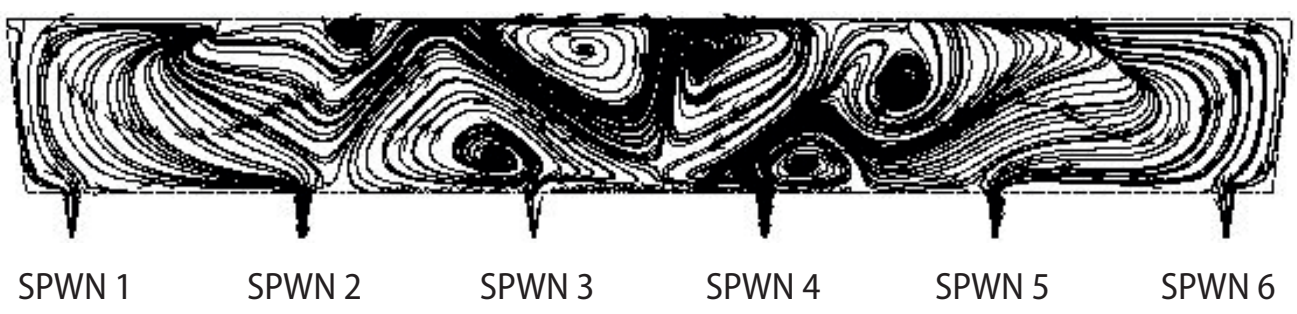

Fig. 2. Fields of liquid steel flow in the examined tundish: a) case $1 ;$ b) case 2; c) case 3; d) case 4 


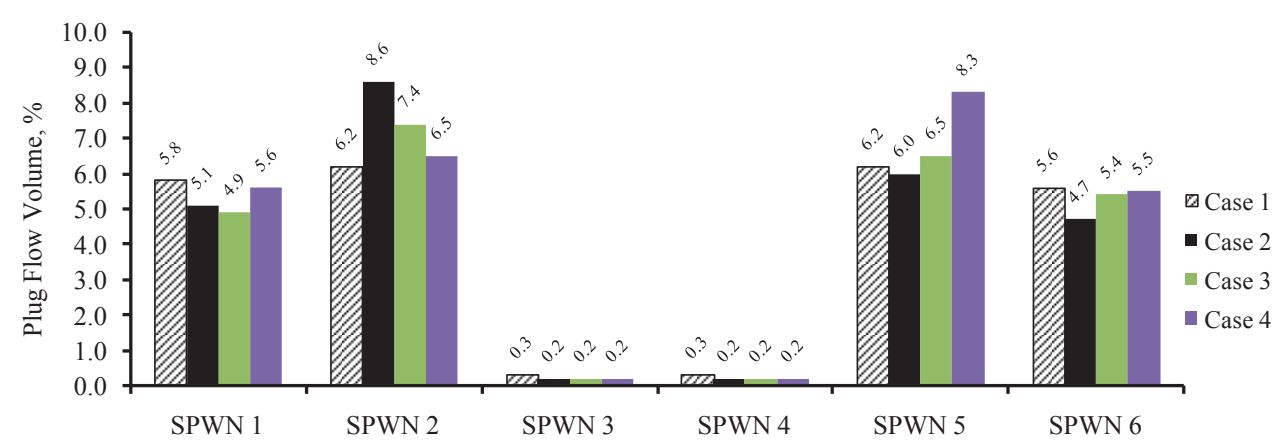

Fig. 3. Plug flow volumes for research cases

Figure 4 presents the percentage volumes of the ideal mixing flow using the considered variants of the tundish. Between SPWNs 1 and 6 in the case with the ladle shroud immersed to a depth of $0.1 \mathrm{~m}$ in the liquid steel, minimal differences in the ideal mixing flow volume was noted $(0.1 \%)$, whereas the greatest difference was observed in Case 3 (2.0\%). The largest volume of the ideal mixing flow was noticed using the ladle shroud immersed to a depth of $0.3 \mathrm{~m}$ in the liquid steel on SPWN 2 (58.6\%). However, between SPWNs 2 and 5 in Case 4, the greatest difference in the ideal mixing volume flow was noted (3.1\%). Analyzing the ideal mixing flow volume between SPWNs 3 and 4, it is easy to see the occurrence of liquid steel asymmetry flow in all of the considered research objects. The smallest difference in the ideal mixing flow volume was noted in the case with the ladle shroud immersed at a depth of $0.2 \mathrm{~m}$ in the liquid steel (1.9\%). The average values of the ideal mixing flow volume (calculated from volumes on all of the SPWNs) for the individual test variants were calculated as follows: Case $1-5$ 5.0\%; Case $2-54.9 \%$; Case 3 - 54.9\%; and Case $4-54.8 \%$.

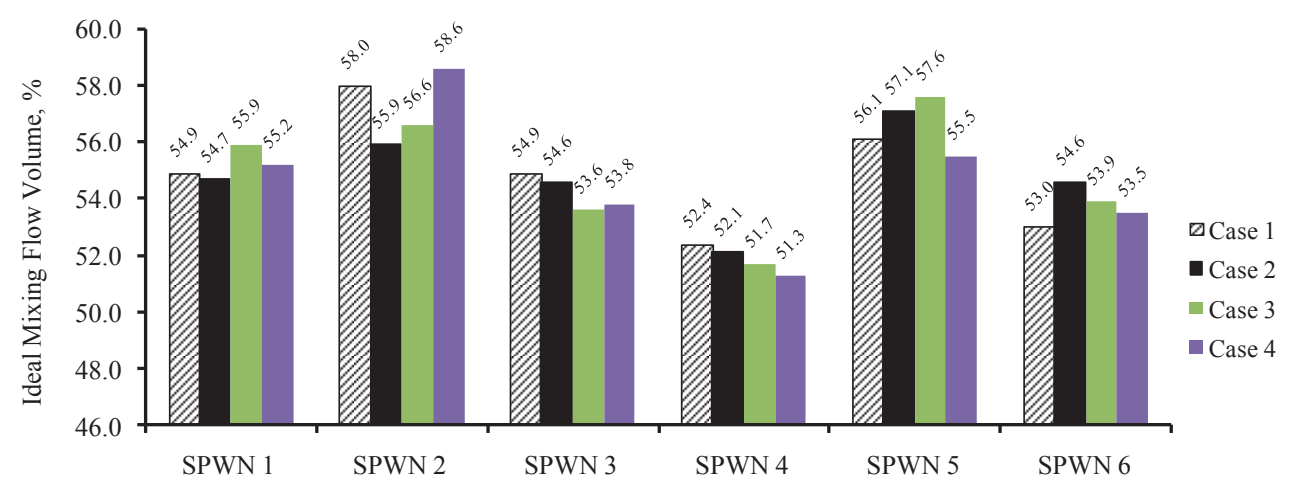

Fig. 4. Ideal mixing flow volumes for research variants 
During the optimization of the tundish working conditions, it is important to minimize the stagnant flow volume; this may a negative influence on the process of floating non-metallic inclusions to the tundish slag. Figure 5 shows the percentage volumes of the stagnant flow. As compared to the results of the ideal mixing flow volume on the individual SPWNs (and the research cases), the differences in the stagnant flow volume between the SPWNs from all research cases are insignificant. The greatest average volume of stagnant flow (46.7\%) was recorded on SPWNs 3 and 4 (for all of the tested variants), whereas the smallest average volume of stagnant flow was recorded on SPWNs 2 and $5(36.1 \%)$. The average volume of the stagnant flow for Cases 1, 2, and 3 was the same (41.0\%); in the case of the ladle shroud immersion depth of $0.3 \mathrm{~m}$ in the liquid steel, it was slightly lower (40.9\%). However, there are differences on the limit of a numeric error.

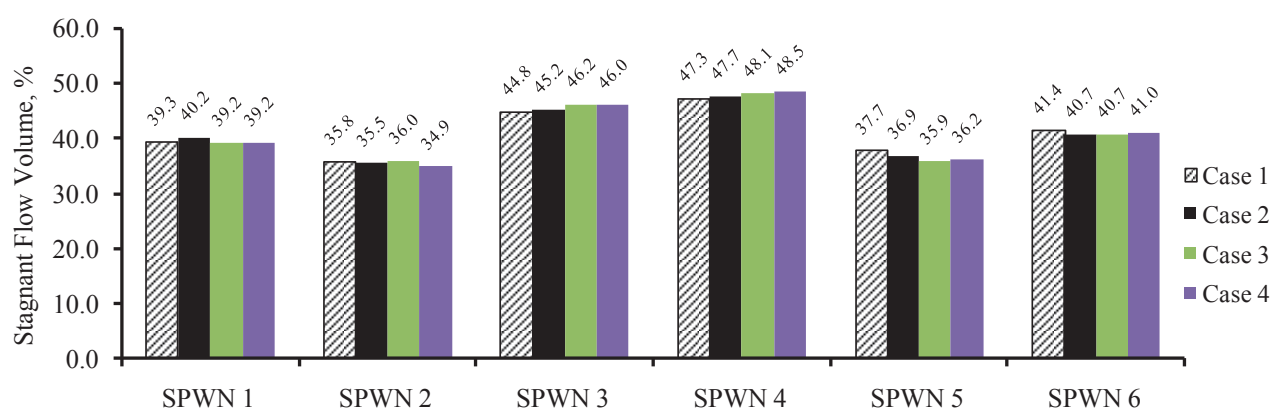

Fig. 5. Stagnant flow volumes for research variants

Figure 6 presents the weights of the casting billets during the moment of mixing two steel grades in the tundish (transition zone) for the individual research cases. For the individual research variants, the average range of the transition zone was recorded; then, the weights of the cast billets were calculated. The shortest average transition zone (768 s) was achieved in the variant with a ladle shroud immersion depth of $0.3 \mathrm{~m}$ in the liquid steel ( $4.82 \mathrm{Mg}$ of the billet), whereas the longest ( $775 \mathrm{~s}$ ) was achieved in the variant without the ladle shroud $(4.87 \mathrm{Mg})$. Figure 7 shows the average differences in the transition zone between SPWNs 1-3 and 4-6 of the considered research cases. The obtained results indicate that the largest asymmetry of liquid steel flow in the tundish was achieved through using a case with a ladle shroud immersion depth of $0.3 \mathrm{~m}$ in the liquid steel. The average difference in the transition zone between SPWNs 1-3 and 4-6 was $29 \mathrm{~s}$. 


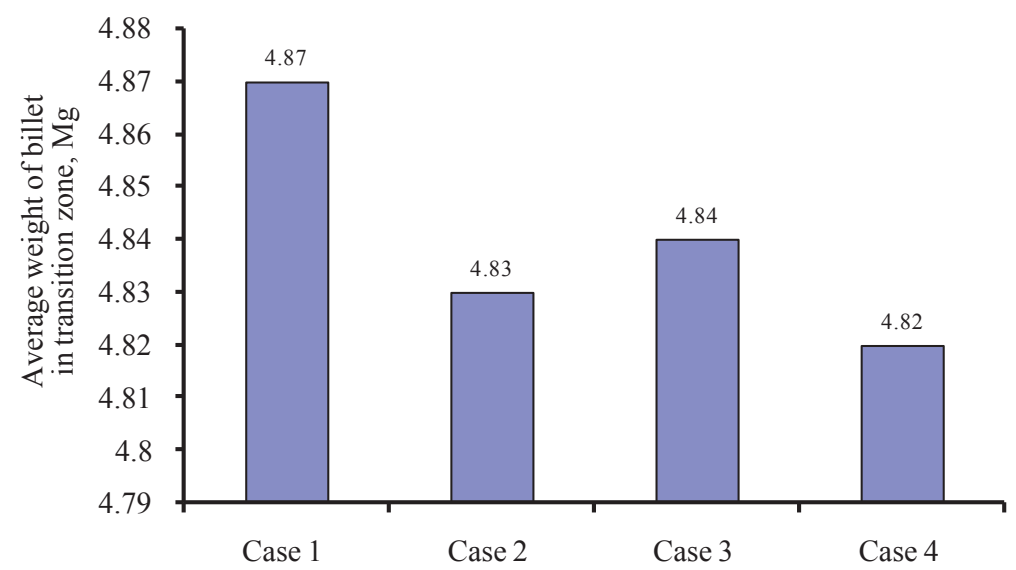

Fig. 6. Average weights of casting billets during moment of mixing two steel grades in tundish (transition zone) for individual research cases

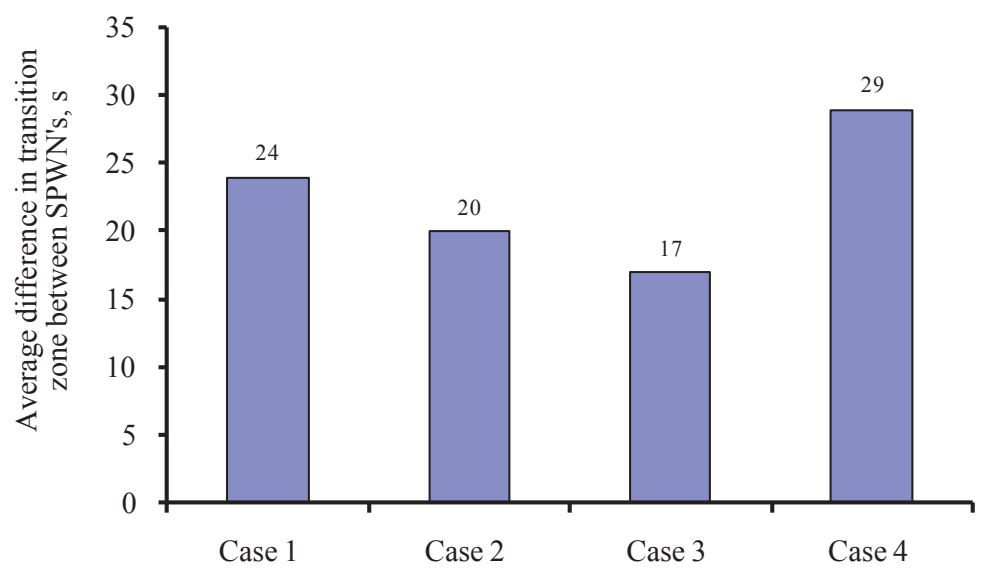

Fig. 7. Average differences in transition zone between SPWNs 1-3 and 4-6 for individual research cases

\section{Summary}

The results of the liquid steel flow numerical simulations in the tundish support the selection of the tundish construction and appropriate FCD for industrial conditions. In this work, liquid steel flow examinations were carried out in a six-strand tundish, which significantly have shown the metal movement hydrodynamic structure in the considered object using a ladle shroud (at different immersion depths). 
Based on the results from the performed works, the following conclusions were made:

- The application and change of the ladle shroud immersion depth does not significantly affect the formation of the active flow volume nor the transition zone.

- The shortest transition zone and the lowest volume of stagnant flow in the tundish were recorded using a ladle shroud immersion depth of $0.3 \mathrm{~m}$ in the liquid steel.

- The character of the liquid steel flow in the considered tundish is asymmetrical.

- The lowest asymmetry of liquid steel flow in the tundish was observed in the case with a ladle shroud immersion depth of $0.2 \mathrm{~m}$ in the liquid steel.

\section{Acknowledgements}

The work was carried out as part of statutory research at the Department of Metal Extraction and Recirculation at the Czestochowa University of Technology.

\section{References}

[1] Bartosiewicz M., Cwudziński A.: Influence of Immersion Depth of Ladle Shroud in Liquid Steel on Range of Transition Zone for One-strand Tundish during Continuous Casting of Steel. Metallurgy and Foundry Engineering, 42, 2 (2017), 81-88

[2] Warzecha M., Merder T., Pfeifer H., Pieprzyca J.: Investigation of Flow Characteristics in a Six-strand CC Tundish Combining Plant Measurements. Physical and Mathematical Modeling, Steel Research International, 81, 11 (2010), 987-993

[3] Mazumdar D., Guthrie R.I.L.: The Physical and Mathematical Modelling of Continuous Casting Tundish Systems. ISIJ International, 39, 6 (1999), 524-547

[4] Sahai Y., Emi T.: Melt Flow Characterization in Continuous Casting Tundishes. ISIJ International, 36, 6 (1996), 667-672

[5] Yang X., Liu S., Jiao J., Zhang M., Duan J., Li L., Liu C.: Hydrodynamic Modeling and Mathematical Simulation of Flow Fields and Temperature Profile for Molten Stainless Steel in an Asymmetrical T-type Single-strand Continuous Tundish with Arch or Round Hole(s) at Dam Bottom. Steel Research International, 83,3 (2012), 269-287

[6] Merder T., Pieprzyca J.: Optimization of Two-strand Industrial Tundish Work with Use of Turbulence Inhibitor: Physical and Numerical Modeling. Steel Research International, 83, 11 (2012), 1029-1038

[7] Meijie Z., Huazhi G., Ao H., Hongxi Z., Chengji D.: Numerical Simulation and Industrial Practice of Inclusion Removal from Molten Steel by Gas Bottom-blowing in Continuous Casting Tundish. Journal of Mining Metallurgical: Section B, 47, 2 (2011), 137-147

[8] Zhang M.J., Gu H.Z., Huang A., Zhu H.X., Deng C.J.: Physical and Mathematical Modeling of Inclusion Removal with Gas Bottom-blowing in Continuous Casting Tundish. Journal of Mining Metallurgical: Section B, 47, 1 (2011), 37-44

[9] Falkus J., Drożdż P.: Assessing Continuous Casting Tundish Operation with a New-generation Impact Pad. Metallurgy and Foundry Engineering, 30, 1 (2004), 23-30

[10] Solorio-Diaz G., Davila-Morales R., Barreto-Sandoval J.D.J., Vargara-Hernandez H.J., Ramos-Banderas A., Galvan S.R.: Numerical Modelling of Dissipation Phenomena in a New Ladle Shroud for Fluidynamic Control and its Effect on Inclusions Removal in a Slab Tundish. Steel Research International, 85, 5 (2013), 863-874 
[11] Chattopadhyay K., Isac M., Guthrie R.I.L.: Physical and Mathematical Modelling of Inert Gas Shrouding in a Tundish. ISIJ International, 51, 4 (2011), 573-580

[12] Wang G., Yun M., Zhang C., Xiao G.: Flow Mechanism of Molten Steel in a Single-strand Slab Caster Tundish Based on the Residence Time Distribution Curve and Data. ISIJ International, 55, 5 (2015), 984-992

[13] Siddiqui M.I.H., Jha P.K.: Numerical Investigation of Inclusion Behaviour in a Multi-strand Tundish during Strand Blockages. Journal of the Institution of Engineers (India): Series D, 96, 2 (2015), 123-130

[14] Cwudziński A., Jowsa J.: Numerical Simulation Heat Transfer in the Slab Tundish. Metallurgy and Foundry Engineering, 33, 2 (2007), 97-103 